Kalamatika: Jurnal Pendidikan Matematika

Volume 4, No. 2, September 2019, hal. 205-214

$\mathbf{K} / \mathbf{L} / \mathbf{M} / \mathbf{T} / \mathbf{K}$

\title{
KECEMASAN MATEMATIK DAN KEMAMPUAN PEMECAHAN MASALAH MATEMATIS SISWA SMA
}

\author{
Wahyu Hidayat ${ }^{1}$, Delifya B. Ayudia ${ }^{2}$ \\ ${ }^{1}$ Institut Keguruan dan Ilmu Pendidikan Siliwangi \\ wahyu@ikipsiliwangi.ac.id \\ ${ }^{2}$ Institut Keguruan dan Ilmu Pendidikan Siliwangi \\ delifya@ikipsiliwangi.ac.id
}

\begin{abstract}
ABSTRAK
Penelitian ini bertujuan untuk menganalisis dan menelaah secara mendalam tentang kecemasan dan pemecahan masalah matematik siswa SMA. Metode penelitian yang digunakan merupakan metode korelasional. Populasi dalam penelitian ini adalah siswa SMA di Bandung Barat. Sedangkan sampelnya sebanyak 27 orang yang ditetapkan secara purposif pada salah satu SMA di Bandung Barat. Instrumen dalam penelitian ini merupakan tes dan non tes. Hasil penelitian menyimpulkan bahwa kemampuan pemecahan masalah matematis siswa SMA dipengaruhi negatif oleh kecemasan matematik sebesar 57,1\% sedangkan $42,9 \%$ dipengaruhi oleh faktor lain di luar kecemasan matematik siswa.
\end{abstract}

Kata Kunci: pemecahan masalah, kecemasan matematik, korelasi

\begin{abstract}
This research aims to analyze and examine deeply about the students' mathematical anxiety and mathematical problem-solving of high school students. The research method used the correlational. The population in this research are high school students in West Bandung. Meanwhile, the sample of this research is 27 people that are purposively assigned to one of high schools in Cihampelas. Instruments used in this research are tests and non-tests. The results of this research shows that the abilities of mathematical problem solving of high school students are negatively affected by $57.1 \%$ of mathematical anxiety while $42.9 \%$ is influenced by other factors beyond students' mathematical anxiety.
\end{abstract}

Keywords: mathematical problem solving, mathematical anxiety, correlational

Format Sitasi: Hidayat., \& Ayudia. (2019). Kecemasan matematik dan kemampuan pemecahan masalah matematis siswa SMA. Kalamatika: Jurnal Pendidikan Matematika, 4(2), 205-214.

Penyerahan Naskah: 8 November 2019 || Revisi: 21 November 2019 || Diterima: 22 November 2019 


\section{PENDAHULUAN}

Kemampuan pemecahan masalah merupakan kemampuan yang sangat penting dan harus dimiliki oleh peserta didik. Hal ini dikarenakan di dalam kemampuan pemecahan masalah menuntut siswa untuk memahami dan menyelesaikan permasalahan matematika yang diberikan secara komprehensif (Hidayat, 2017). Namun kenyataan di lapangan, kemampuan pemecahan masalah matematik masih belum digunakan secara optimal oleh siswa. Hal ini dikarenakan cara penyampaian yang dilakukan oleh pendidik juga belum optimal dalam menyampaikan pembelajaran matematika baik ditinjau berdasarkan hal teknis seperti materi, maupun berdasarkan hal non teknis seperti fasilitas sarana prasarana yang dimiliki oleh sekolah (Hidayat \& Sariningsih, 2018).

Kemampuan pemecahan masalah sebagai suatu proses meliputi beberapa kegiatan dalam proses penyelesaiannya yaitu memahami dan merumuskan masalah (understand the problem), menyusun renana dan memilih strategi yang sesuai (device a plan), melaksanakan rencana dan strategi yang tepat (carry out the plan) dan memeriksa kembali proses dan hasil yang diperoleh. Setiap tahap yang dilalui berurutan saling mendukung untuk menghasilkan pemecahan masalah yang tercantum di dalam soal.

Proses dalam kegiatan pemecahan masalah matematis berbeda dengan proses penyelesaian soal matematika lainnya. Apabila jawaban pada soal yang diberikan sangat mudah dan dapat segera terselesaikan, maka soal tersebut termasuk kedalam soal rutin dan bukan merupakan suatu masalah baru bagi siswa. Sebab proses penyelesaian masalah matematika bagi siswa itu dapat bermakna sebuah tantangan yang harus diselesaikan (Hidayat \& Sariningsih, 2018).

Adapun beberapa penyebab kurangnya siswa dalam pemecahan masalah matematis, salah satu penyebab tersebut adalah perasaan cemas yang dialami siswa pada saat pembelajaran matematika hingga menimbulkan perasaan-perasaan lain seperti menurunnya tingkat self-confidence, kemandirian belajar serta beberapa perasaan-perasaan lain yang tentu sangat dapat mempengaruhi siswa dalam proses penerimaan informasi matematika yang berdampak pula pada kemampuannya dalam memecahkan suatu masalah matematika.

Trujillo \& Hadfield (Peker, 2009) menyatakan bahwa penyebab kecemasan dalam pembelajaran matematika dapat diklasifikasikan dalam tiga kategori yaitu Faktor kepribadian (psikologis atau emosional), Faktor lingkungan atau sosial, Faktor intelektual. 
Faktor kepribadian (psikologis atau emosional) misalnya perasaan takut siswa akan kemampuan yang dimilikinya (self-efficacy belief), kepercayaan diri yang rendah yang menyebabkan rendahnya nilai harapan siswa (expectancy value), motivasi diri siswa yang rendah dan sejarah emosional seperti pengalaman tidak menyenangkan dimasa lalu yang berhubungan dengan matematika yang menimbulkan trauma.

Faktor lingkungan atau sosial misalnya kondisi saat proses belajar mengajar matematika di kelas yang tegang diakibatkan oleh cara mengajar, model dan metode mengajar guru matematika. Rasa takut dan cemas terhadap matematika dan kurangnya pemahaman yang dirasakan para guru matematika dapat terwariskan kepada para siswanya. Faktor yang lainnya bersumber dari keluarga yang memaksakan anaknya untuk pandai dalam matematika karena matematika dipandang sebagai sebuah ilmu yang memiliki nilai prestise.

Faktor intelektual terdiri atas pengaruh yang bersifat kognitif, yaitu lebih mengarah pada bakat dan tingkat kecerdasan yang dimiliki siswa. Hasil penelitian yang dilakukan menunjukkan bahwa ada korelasi antara kecemasan matematika dan kemampuan verbal atau bakat serta Intelectual Quotion (IQ).

Richardson \& Suinn (1972) menyatakan bahwa kecemasan matematika melibatkan rasa cemas yang mempengaruhi terhadap cara memecahkan permasalahan matematika yang dikaitkan dengan permasalahan sehari-hari. Hal ini sejalan dengan yang dikemukakan oleh Ashcraft (2002) bahwa kecemasan matematik merupakan sebagai perasaan tegang, cemas, serta ketakutan yang dimiliki seseorang sehingga mempengaruhi faktor terhambatkan seseorang melakukan kinerja dalam matematika. Hal ini dapat menyebabkan seseorang untuk melakukan menghindar dalam situasi belajar pada pelajaran matematika. Siswa yang mengalami cemas dalam belajar matematika akan memiliki perasaan yang dapat menyebabkan siswa tersebut sukar atau tidak dapat menyelesaikan masalah dalam matematika, serta sulit untuk menerima pelajaran matematika yang diajarkan oleh guru (Anita, 2014).

Keterkaitan kecemasan matematis terhadap kemampuan matematis sebenarnya sudah banyak yang melakukan penelitian sebelumnya, namun terkait penelitian yang mengkaji kecemasan matematis terhadap kemampuan pemecahan masalah matematis pada siswa SMA dirasa belum ada yang melakukan pengkajian tersebut. Dengan demikian, sudah menjadi suatu hal yang urgen untuk dilakukan penelitian tentang keterkaitan kecemasan matematik dengan kemampuan pemecahan masalah matematis siswa SMA. Sehingga pertanyataan dalam 
penelitian ini lebih difokuskan apakah kecemasan matematik memberikan pengaruh yang negatif terhadap kemampuan pemecahan masalah matematik siswa SMA?

\section{METODE PENELITIAN}

Metode dalam penelitian ini merupakan metode korelasional yang memiliki tujuan untuk menelaah secara komprehensif tentang peranan kecemasan matematik siswa SMA terhadap kemampuan pemecahan masalah matematis. Populasi dalam penelitian ini adalah siswa SMA di Kabupaten Bandung Barat. Sedangkan sampelnya sejumlah 27 siswa di salah satu SMA di Kabupaten Bandung Barat. sampel tersebut merupakan representasi dari populasi. Instrumen penelitian menggunakan tes sebanyak 5 butir soal dan non tes sebanyak 36 pernyataan.

Untuk memperoleh kesimpulan dalam penelitian ini, dilakukan juga pengujian data hasil penelitian dengan menggunakan uji statistika normitas, uji linearitas dan uji regresi. Adapun salah satu masalah yang diberikan kepada siswa pada penelitian ini disajikan pada Gambar 1 dan 2.

Ibu mempunyai sebuah taman berbentuk jajargenjang. Diketahui panjang sisi alas taman $\mathrm{AB}$ adalah $7 \mathrm{~m}$, dan panjang sisi miring taman $\mathrm{AD}$ adalah $6 \mathrm{~m}$, sedangkan panjang salahsatu diagonal tamannya yaitu BD $8 \mathrm{~m}$. Tentukan nilai kosinus sudut yang terbentuk antara panjang sisi alas taman $\mathrm{AB}$ dan panjang sisi miring taman $\mathrm{AD}$ !

Gambar 1. Instrumen kemampuan pemecahan masalah matematis

KISI-KISI KECEMASAN MATEMATIKA

(ANXIETY MATHEMATICS)

\begin{tabular}{|c|c|c|c|c|c|c|c|c|}
\hline No & Kriteria & Komponen & & Pernyataan & SS & $\mathbf{S}$ & $\mathbf{J}$ & $\mathbf{T P}$ \\
\hline \multirow[b]{8}{*}{1} & \multirow{8}{*}{$\begin{array}{c}\text { Kecemasan } \\
\text { terhadap } \\
\text { pembelajaran } \\
\text { matematika }\end{array}$} & \multirow{4}{*}{ Psikologis } & 1 & $\begin{array}{l}\text { Saya menikmati belajar matematika selama } \\
\text { di kelas }(+)\end{array}$ & & & & \\
\hline & & & 2 & $\begin{array}{l}\text { Saya percaya dapat mengerjakan soal yang } \\
\text { diberikan oleh guru }(+)\end{array}$ & & & & \\
\hline & & & 3 & $\begin{array}{l}\text { Saya ingin jam pelajaran matematika cepat } \\
\text { berakhir (-) }\end{array}$ & & & & \\
\hline & & & 4 & $\begin{array}{l}\text { Belajar matematika membuat saya tidak } \\
\text { percaya diri (-) }\end{array}$ & & & & \\
\hline & & \multirow{4}{*}{ Fisiologi } & 5 & $\begin{array}{l}\text { Jantung saya berdetak lebih cepat saat } \\
\text { belajar matematika (-) }\end{array}$ & & & & \\
\hline & & & 6 & $\begin{array}{l}\text { Saya merasa tertekan selama pelajaran } \\
\text { matematika di kelas (-) }\end{array}$ & & & & \\
\hline & & & 7 & $\begin{array}{l}\text { Saya mudah mengerti pada materi yang } \\
\text { dijelaskan di kelas }(+)\end{array}$ & & & & \\
\hline & & & 8 & $\begin{array}{l}\text { Saya merasa tenang jika guru matematika } \\
\text { menyuruh saya mengerjakan soal di papan } \\
\text { tulis }(+)\end{array}$ & & & & \\
\hline
\end{tabular}

Gambar 2. Instrumen kecemasan matematik 


\section{HASIL DAN PEMBAHASAN}

Hasil penelitian menunjukkan bahwa sebaran data kecemasan matematik dan kemampuan pemecahan masalah matematik berdistribusi normal, sehingga dilakukan uji statistika linearitas data kecemasan matematik terhadap kemampuan pemecahan masalah matematika (Tabel 1).

Tabel 1. Uji Linearitas antara Kecemasan Matematik dan Kemampuan Pemecahan Masalah Siswa

\begin{tabular}{|c|c|c|c|c|c|c|c|}
\hline & & & $\begin{array}{l}\text { Sum of } \\
\text { Squares }\end{array}$ & $\mathrm{df}$ & $\begin{array}{l}\text { Mean } \\
\text { Square }\end{array}$ & $\mathrm{F}$ & Sig. \\
\hline \multirow{4}{*}{$\begin{array}{l}\text { kemampuan } \\
\text { pemecahan } \\
\text { masalah * } \\
\text { kecemasan } \\
\text { matematik }\end{array}$} & \multirow{3}{*}{ Between Groups } & (Combined) & 208,380 & 19 & 10,967 & 3,040 & 0,069 \\
\hline & & \multirow{3}{*}{$\begin{array}{l}\text { Linearity } \\
\text { Deviation from } \\
\text { Linearity }\end{array}$} & 133,503 & 1 & 133,503 & 37,011 & 0,000 \\
\hline & & & 74,877 & 18 & 4,160 & 1,153 & 0,450 \\
\hline & $\begin{array}{l}\text { Within Groups } \\
\text { Total }\end{array}$ & & $\begin{array}{r}25,250 \\
233,630\end{array}$ & $\begin{array}{c}7 \\
26\end{array}$ & 3,607 & & \\
\hline
\end{tabular}

Berdasarkan uji linearitas pada Tabel 1, diperoleh kesimpulan bahwa antara kecemasan dan kemampuan pemecahan masalah matematik terdapat hubungan yang linear (Sig. 0,450 > $\alpha$ $=5 \%$ ). Hal ini juga mengakibatkan bahwa tingkat linearitas antara kecemasan matematik dan kemampuan pemecahan masalah tergolong kuat $(\mathrm{Sig} .=0,000)$.

Tabel 2. Uji Regresi antara Kecemasan Matematik dan Kemampuan Pemecahan Masalah Matematik

\begin{tabular}{lllllll}
\hline Model & & $\begin{array}{l}\text { Sum of } \\
\text { Squares }\end{array}$ & df & $\begin{array}{l}\text { Mean } \\
\text { Square }\end{array}$ & F & Sig. \\
\hline \multirow{3}{*}{1} & Regression & 133,503 & 1 & 133,503 & 33,333 & $0,000^{\mathrm{b}}$ \\
& Residual & 100,127 & 25 & 4,005 & & \\
& Total & 233,630 & 26 & & & \\
\hline
\end{tabular}

a. Dependent Variable: kemampuan pemecahan masalah

b. Predictors: (Constant), kecemasan matematik

Berdasarkan pengujian regresi pada Tabel. 2, di dapat Sig. sebesar 0,000. Hal ini menunjukkan bahwa kecemasan matematik memberikan pengaruh yang positif pada kemampuan pemecahan masalah matematis. Berdasarkan Tabel 3 menunjukkan bahwa diperolehnya nilai dari koefisien korelasi sebesar 0,756 dan koefisien determinasi yaitu 0,571 (57.1\%). Hal ini menunjukkan kemampuan pemecahan masalah matematis siswa dipengaruhi secara langsung oleh kecemasan matematik siswa sebesar $57,1 \%$ dan $42,9 \%$ oleh faktor selain kecemasan matematik.

Tabel 3. Model Summary

\begin{tabular}{lcccc}
\hline Model & $\mathrm{R}$ & $\mathrm{R}$ Square & $\begin{array}{c}\text { Adjusted } \\
\text { R Square }\end{array}$ & $\begin{array}{c}\text { Std. Error of the } \\
\text { Estimate }\end{array}$ \\
\hline 1 & $0,756^{\mathrm{a}}$ & 0,571 & 0,554 & 2,001 \\
\hline
\end{tabular}

a. Predictors: (Constatnt), Kecemasan Matematika 
Adapun persamaan regresi dari hasil pengujian tentang pengaruh kecemasan matematik terhadap kemampuan pemecahan masalah matematis siswa adalah sebagai berikut: $Y=21,744-0,080 x$

Hal ini dapat diinterpretasikan bahwa apabila kecemasan matematik siswa bernilai 0 (nol) maka kemampuan pemecahan masalah siswa bernilai 21,744. Berdasarkan persamaan regresi juga diperoleh bahwa koefisien dari kecemasan matematik memiliki nilai negatif artinya pengaruh yang diberikan oleh kecemasan matematik memiliki dampak yang negative terhadap pencapaian kemampuan pemecahan masalah matematik siswa. Sehingga dapat disimpulkan apabila kecemasan matematik yang dimiliki siswa semakin tinggi, maka akan memberikan dampak kemampuan pemecahan masalah matematis siswa yang rendah.

Berdasarkan hasil penelitian, diperoleh kesimpulan bahwa kecemasan matematik memberikan pengaruh yang negatif pada kemampuan pemecahan masalah matematis siswa. Salah satu penyebab terjadinya pengaruh negatif tersebut diasumksikan karena siswa yang memiliki kecemasan matematik cenderung takut dalam menyelesaikan soal di luar prosedur pada umumnya. Selain itu siswa yang memiliki kecemasan matematik cenderung sulit menemukan ide dalam penyelesaian soal. Dengan demikian bagi siswa yang memiliki kecemasan yang tinggi kemungkinan akan cenderung menyelesaikan soal sesuai dengan prosedur atau bahkan tidak akan menyelesaikannya sama sekali, sehingga siswa tersebut menjadi lemah dalam pengambilan keputusan saat proses penyelesaian masalah yang dialaminya (Prahmana, Sutanti, Wibawa \& Diponegori, 2019).

Hal tersebut dapat dikuatkan berdasarkan hasil pekerjaan siswa dengan kecemasan matematik berdasarkan kategori rendah dan tinggi yang disajikan pada Gambar 3 dan Gambar 4 berikut.

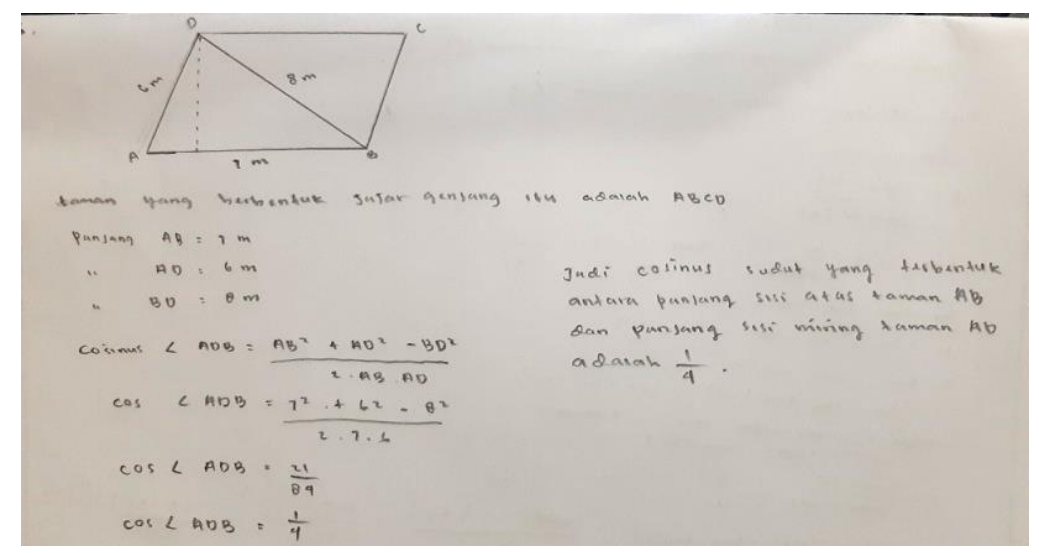

Gambar 3. Pekerjaan Siswa dengan kecemasan matematik rendah 


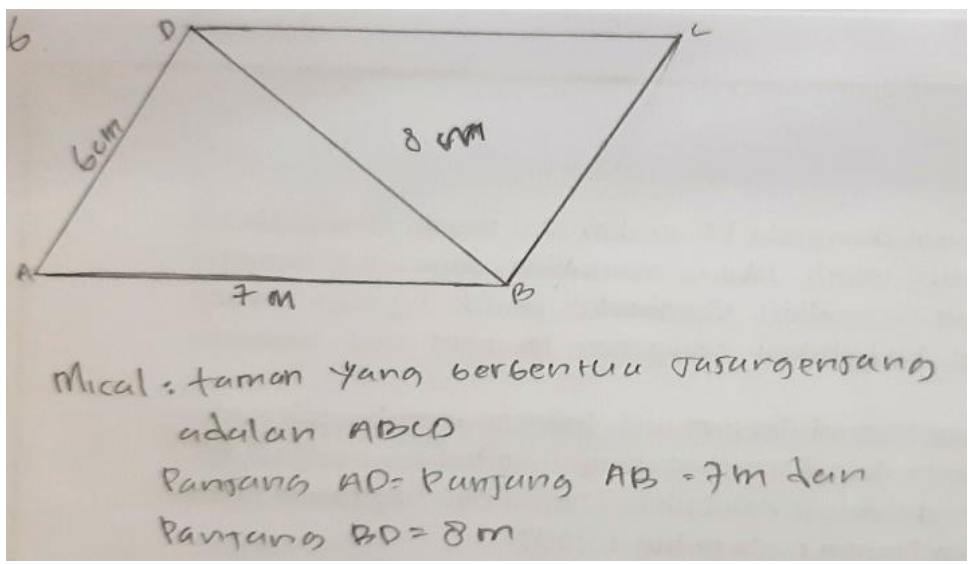

Gambar 4. Pekerjaan siswa dengan kecemasan matematik tinggi

Pada Gambar 3, siswa melakukan langkah penyelesaian dengan melakukan ilustrasi berupa situasi pada soal yang diperintahkan. Hal ini siswa diperintahkan untuk mencari penyelesaian dari permasalahan. Pada akhirnya siswa mampu memperoleh Ide awal dalam menyusun strategi yang dilakukannya, sehingga merasa sudah dianggap tepat dalam menemukan jawabannya. Namun bagi siswa yang memiliki kecemasan tinggi terlihat bahwa siswa tersebut hanya menggambar sebuah jajar genjang dan ia hanya menuliskan tahap diketahuinya saja tanpa menyelesaikan seluruhnya. Gambar 4 memperlihatkan siswa memiliki perasaan cemas yang dialaminya mengakibatkan kurangnya membangun ide serta motivasi untuk menyelesaikan permasalahan yang diberikan.

Berkaitan dengan hasil penelitian yang menyatakan bahwa kecemasan matematik memberikan pengaruh yang negatif terhadap kemampuan pemecahan masalah matematik dikarenakan mata pelajaran matematika sering dianggap membosankan sehingga siswa merasa akan sering menghindar dari belajar matematika dan menumbuhkan rasa tidak percaya diri, bosan, dan gugup dalam mengatakan bahwa mata pelajaran matematika itu adalah penting (Furner \& Berman, 2003). Selain itu Prahmana et al. (2019) juga yang mengatakan bahwa kecemasan matematik sesungguhnya memiliki hubungan negatif dalam kinerja prestasi matematika. Hal ini dikarenakan kecemasan matematik yang dimiliki peserta didik dipengaruhi berdasarkan beberapa aspek yakni keluarga, masyarakat, budaya di sekolah, serta fisik dan perilaku peserta didik itu sendiri (Furner \& Berman, 2003; Hidayat, 2017; Mensah, Okyere, \& Kuranchie, 2013). 


\section{KESIMPULAN}

Berdasarkan hasil dan pembahasan, maka kecemasan matematik siswa memberikan kontribusi dalam hal mempengaruhi pemecahan masalah matematik sebesar $57,1 \%$ sedangkan sisanya $(42,9 \%)$ bukan dampak dari kecemasan matematik siswa.

\section{REFERENSI}

Anita, I. W. (2014). Pengaruh Kecemasan Matematika (Mathematics Anxiety) terhadap Kemampuan Koneksi Matematis Siswa SMP. Jurnal Ilmiah Program Studi Matematika STKIP Siliwangi Bandung, 3(1), 125-132.

Ashcraft, M. H. (2002). Math Anxiety: Personal, Educational, and Cognitive Consequences. Directions in Psychological Science.

Furner, J. M., \& Berman, B. T. (2003). Review of research: math anxiety: overcoming a major obstacle to the improvement of student math performance. Childhood education, 79(3), 170-174.

Hidayat, W. (2017). Adversity Quotient dan Penalaran Kreatif Matematis Siswa SMA dalam Pembelajaran Argument Driven Inquiry pada Materi Turunan Fungsi. KALAMATIKA Jurnal Pendidikan Matematika, 1(2), 15-28.

Hidayat, W., \& Sariningsih, R. (2018). Kemampuan Pemecahan Masalah Matematis dan Adversity Quotient Siswa SMP Melalui Pembelajaran Open Ended. JNPM (Jurnal Nasional Pendidikan Matematika), 2(1), 109-118.

Mensah, J. K., Okyere, M., \& Kuranchie, A. (2013). Student attitude towards mathematics and performance: Does the teacher attitude matter. Journal of Education and Practice, 4(3), 132-139.

Peker, M. (2009). "Pre-Service Teachers' Teaching Anxiety about Mathematics and Their Learning Styles.” Eurasia Journal of Mathematics, Science, \& Technology Education, $4(5), 335-345$.

Prahmana, R. C. I., Sutanti, T., Wibawa, A. P., \& Diponegoro, A. M. (2019). Mathematical anxiety among engineering students. Infinity Journal, 8(2), 179-188. 
Richardson, F. C., \& Suinn, R. M. (1972). The Mathematics Anxiety Rating Scale: Psychometric Data. Journal of Counseling Psychology, 6(19), 551-554. 
Hidayat \& Ayudia 214 